\title{
Stratospheric ozone measurements at Arosa (Switzerland): history and scientific relevance
}

\author{
Johannes Staehelin ${ }^{1}$, Pierre Viatte $^{2}$, Rene Stübi $^{2}$, Fiona Tummon ${ }^{1}$, and Thomas Peter ${ }^{1}$ \\ ${ }^{1}$ Institute for Atmospheric and Climate Science, ETHZ, Zürich, Switzerland \\ ${ }^{2}$ Federal Office of Meteorology and Climatology MeteoSwiss, Payerne, Switzerland \\ Correspondence: Johannes Staehelin (johannes.staehelin@env.ethz.ch)
}

Received: 20 November 2017 - Discussion started: 29 November 2017

Revised: 15 March 2018 - Accepted: 22 March 2018 - Published: 8 May 2018

\begin{abstract}
In 1926 stratospheric ozone measurements began at the Light Climatic Observatory (LKO) in Arosa (Switzerland), marking the beginning of the world's longest series of total (or column) ozone measurements. They were driven by the recognition that atmospheric ozone is important for human health, as well as by scientific curiosity about what was, at the time, an ill characterised atmospheric trace gas. From around the mid-1950s to the beginning of the 1970s studies of high atmosphere circulation patterns that could improve weather forecasting was justification for studying stratospheric ozone. In the mid-1970s, a paradigm shift occurred when it became clear that the damaging effects of anthropogenic ozone-depleting substances (ODSs), such as long-lived chlorofluorocarbons, needed to be documented. This justified continuing the ground-based measurements of stratospheric ozone. Levels of ODSs peaked around the mid1990 s as a result of a global environmental policy to protect the ozone layer, implemented through the 1987 Montreal Protocol and its subsequent amendments and adjustments. Consequently, chemical destruction of stratospheric ozone started to slow around the mid-1990s. To some extent, this raises the question as to whether continued ozone observation is indeed necessary. In the last decade there has been a tendency to reduce the costs associated with making ozone measurements globally including at Arosa. However, the large natural variability in ozone on diurnal, seasonal, and interannual scales complicates the capacity for demonstrating the success of the Montreal Protocol. Chemistry-climate models also predict a "super-recovery" of the ozone layer at mid-latitudes in the second half of this century, i.e. an increase of ozone concentrations beyond pre-1970 levels, as a consequence of ongoing climate change. These factors, and
\end{abstract}

identifying potentially unexpected stratospheric responses to climate change, support the continued need to document stratospheric ozone changes. This is particularly valuable at the Arosa site, due to the unique length of the observational record. This paper presents the evolution of the ozone layer, the history of international ozone research, and discusses the justification for the measurements in the past, present and into future.

\section{Introduction}

The world's longest time series of total (or column) ozone observations is from Arosa in the Swiss Alps, made at the "Light Climatic Observatory" (Lichtklimatisches Observatorium, LKO). This long total ozone dataset is extremely valuable for long-term trend analyses of stratospheric ozone. In addition, other important ozone measurements, such as Umkehr and surface ozone measurements were also made at Arosa. Since the 1970s, when anthropogenic stratospheric ozone depletion became a subject of public concern, the measurements at LKO grew in importance (Staehelin et al., 2016). A comprehensive report on the history of the LKO is presently in preparation (Staehelin and Viatte, 2018). Here we focus on the societal justification for these measurements over the long history of the LKO, particularly highlighting the link to the development of international stratospheric ozone research. This paper is based on the extensive correspondence by F. W. Paul Götz - ozone pioneer and founder of the LKO - which is stored in the LKO archives located at MeteoSwiss in Payerne, Switzerland, as well as on the annual reports of the "Kur- und Verkehrsverein Arosa" (KVV 
Arosa, see below), and on other research. Following Staehelin and Viatte (2018) we divide the history of LKO into five distinct periods (see Sects. 2-6 below). Section 7 looks at the potential pathways into the future of measurements at the LKO. Finally, a summary and conclusions are presented in Sect. 8.

\section{Period 1921-1953: Friedrich Wilhelm Paul Götz}

\subsection{Therapy for tuberculosis prior to the availability of antibiotics}

The first ozone measurements at Arosa were a part of medical research focused on the treatment of pulmonary tuberculosis (TB). Before modern antibiotics became available (a few years after World War II), TB was considered a serious illness with a high mortality rate. The best available therapy for treating TB at the time was believed to be the "rest cure therapy" (as proposed by, e.g. Karl Turban, one of the leading medical doctors in Davos at the time, see e.g. Virchow, 2004). At the end of the 19th century and the beginning of the 20th century many sanatoria and hotels were constructed in Alpine villages, such as Davos and Arosa. During "rest cure therapy", which was more fully developed in the first decades of the 20th century, the patients stayed outside on balconies during the day under strict hygienic conditions, usually for several months at a time. Recovery mainly occurred simply by resting. From a modern medical perspective, such rest under strict hygienic control (in order to prevent reinfection) in special lung clinics was probably indeed the most helpful type of therapy before treatment by antibiotics became possible.

The medical doctors of Davos and Arosa were convinced that the high altitude climate was an important factor for optimal recovery from TB. To study this further, the potentially relevant environmental factors needed to be investigated. By 1905, Turban had already proposed opening an institute aimed to study the scientific effectiveness of the "rest cure therapy" of pulmonary TB (SFI, 1997). However, because of a lack of consensus among medical doctors, this institute was founded only 17 years later in 1922 . On 26 March 1922, the municipality of Davos ("Landsgemeinde") decided to create a foundation for an institute for high mountain physiology and tuberculosis research ("Institut für Hochgebirgsphysiologie und Tuberkuloseforschung", today the "Schweizerisches Forschungsinstitut für Hochgebirgsklima und Medizin, SFI" in Davos). The resources for operating the institute mainly originated from a small fee that was paid by all guests of staying in the town, who needed to register when staying in Davos (a form of "tourist tax").

At this point, Carl Dorno played an important role. He was a rich industrialist from Königsberg (then Germany, now Kaliningrad, Russia), who came to Davos because his daughter suffered from pulmonary TB. She unfortunately passed away a few years after arriving in Davos, but Dorno remained and founded an institute to study the environmental factors important for treating TB using his own funds in 1907 (SFI, 1997). During World War I and in the subsequent period of inflation, Dorno lost most of his financial resources. On 18 February 1923, the municipality of Davos decided to support the Observatory Dorno, the nucleus of the renowned Physical Meteorological Observatory Davos (PMOD), which since 1971 has also served as the World Radiation Center (WRC) of the World Meteorological Organization (WMO), a centre for international calibration of meteorological radiation standards within the global network. When Dorno retired as director in 1926, the institute was integrated as an independent department into the Swiss research institute for high mountain physiology and tuberculosis research in Davos and was financed by the Davos community, similar to the other institutes. However, despite numerous studies, it was never shown that the Alpine climate was a superior environment for recovery from pulmonary TB (Schürer, 2017).

\subsection{F. W. P. Götz and the foundation of the LKO (LKS)}

Friedrich Wilhelm Paul Götz grew up in Southern Germany (Göppingen, close to Stuttgart) and went to Davos for the first time prior to the beginning of the World War I to recover from pulmonary $\mathrm{TB}$, when he was working on his $\mathrm{PhD}$ thesis in astronomy (see Fig. 1). He stayed twice in the "Deutsche Heilstätte" sanatorium (1914-1915) after which he was released as "fit for work". In the following years (1916-1919) he intermittently taught at the "Fridericianum" German school in Davos and later worked with Dorno (probably for some months) during the 1919-1920 period. See Staehelin and Viatte (2018) for more details.

It appears that Götz was the main driver behind the initiative to make atmospheric measurements at Arosa. He likely first contacted the Arosa medical doctors and together they subsequently made a request to the managing committee of the KVV Arosa in March 1921 to initiate climate studies relevant for health. The KVV Arosa (Kur- und Verkehrsverein Arosa) was an organization that had a fairly large budget. It was supported mainly through the "tourist" tax, a fee paid by foreigners and guests staying in Arosa, which was also used to cover the costs of various other activities that nowadays are considered a communal responsibility. Götz's request was supported by the General Assembly of the KVV Arosa on 20 August 1921, and Götz was asked to found the "Light Climatic Station" (LKS), which later became known as the "Light Climatic Observatory (LKO)". The objectives of the LKS were to complement the meteorological observations made at Arosa since 1884 by the Swiss national weather service (now "MeteoSwiss") by measurements which were thought to be relevant for studying the recovery from pulmonary TB. Thus, in 1921 Arosa was the first municipality to finance an institute with the task of studying environmental factors favourable to curing (pulmonary) TB. The support 


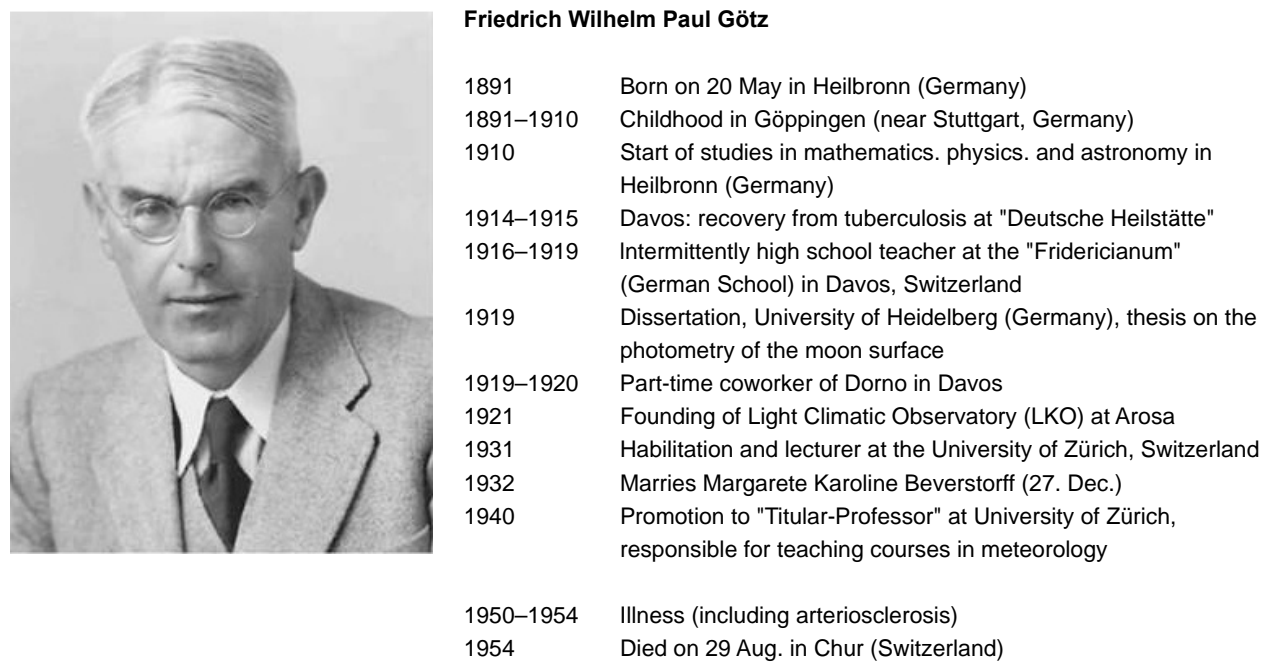

Figure 1. Biography of F. W. Paul Götz, founder of the Light Climatic Observatory in Arosa.

Götz obtained from the KVV Arosa was rather modest and he later secured additional regular funding from the Chur-Arosa railway company, the Arosa municipality, and the canton of Grisons (for more detail see Staehelin and Viatte, 2018). The LKS measurements were made on the roof of the Inner-Arosa Sanatorium, where the "Grand Hotel Tschuggen" is now located (see Fig. 2).

For the first few years Götz was able to borrow an instrument from Dorno (who was based in Davos, see Sect. 2.1) to measure "biologically active ultraviolet (UV) radiation". This instrument had been adapted and used by Dorno and consisted of a photoelectric cell with a cadmium (Cd) cathode (Levy, 1932). Götz published several papers using measurements covering the period November 1921-May 1923 (Götz, 1925, 1926a, b). He found the first indication of seasonal variability of stratospheric ozone in the northern mid-latitudes, with a minimum in autumn and maximum in spring. This turned out to be a very important result later contributing to the development of a better understanding of stratospheric circulation patterns. This seasonal cycle represents one pillar on which the modern understanding of the Brewer-Dobson circulation rests. In fact, Götz published this result earlier than the well known publication of Dobson and Harrison (1926). Dorno did not agree with Götz's Cd-cell results, and this led to an open dispute published in the literature (Dorno, 1927). It seems likely that there were also some personal difficulties between Dorno (who was 26 years older) and Götz, which surfaced with time. It also appears there were issues between the physicians from Davos and Arosa, with the latter suggesting that the scientific studies made in Arosa should be coordinated with those from Davos. They also asked that the institute for high mountain physiology and tuberculosis research in Davos (Institut für Hochgebirgsphysiologie und Tuberkuloseforschung in Davos) be re- named to include Arosa. These efforts failed, as members of the Davos community probably wanted a larger financial contribution from Arosa for the institute (based on the principle of equal duties, equal rights "gleiche Rechte, gleiche Pflichten"). However, the KVV Arosa was not willing to pay the requested amount.

\subsection{LKO under Götz}

1926 was an important year for Götz. After the sobering debate regarding cooperation between the Arosa and Davos medical doctors (for more details see Staehelin and Viatte, 2018) Götz moved into the "Villa Firnelicht" (see Fig. 3), which is very close to the Inner-Arosa Sanatorium, where measurements had been previously performed (see Fig. 2). Evidence suggests that Götz used family resources to build the large house, probably the inheritance from his father, Paul Götz, who owned an ironmongery ("Eisenwarenhandlung”) in Göppingen (Trenkel, 1954) and died in 1926. "Villa Firnelicht" offered space for atmospheric observations on the roof and a balcony. It hosted three apartments and was therefore too large for just Götz and his wife. When Götz moved into "Villa Firnelicht" the institute was renamed the "Light Climatic Observatory" (Lichtklimatisches Obervatorium (LKO)). Götz invited colleagues to come to the LKO for sabbatical-type collaborations and to make atmospheric observations.

Hartley (1881) was the first to postulate that atmospheric ozone is responsible for absorbing solar light in the UV-B spectrum. As the amount of biologically active UV-radiation is determined by stratospheric ozone levels, Götz devoted a large part of his time to stratospheric ozone research (see Staehelin and Viatte, 2018). He realised that studying stratospheric ozone required suitable instrumentation and using resources from the KVV Arosa he mandated the Schmidt- 


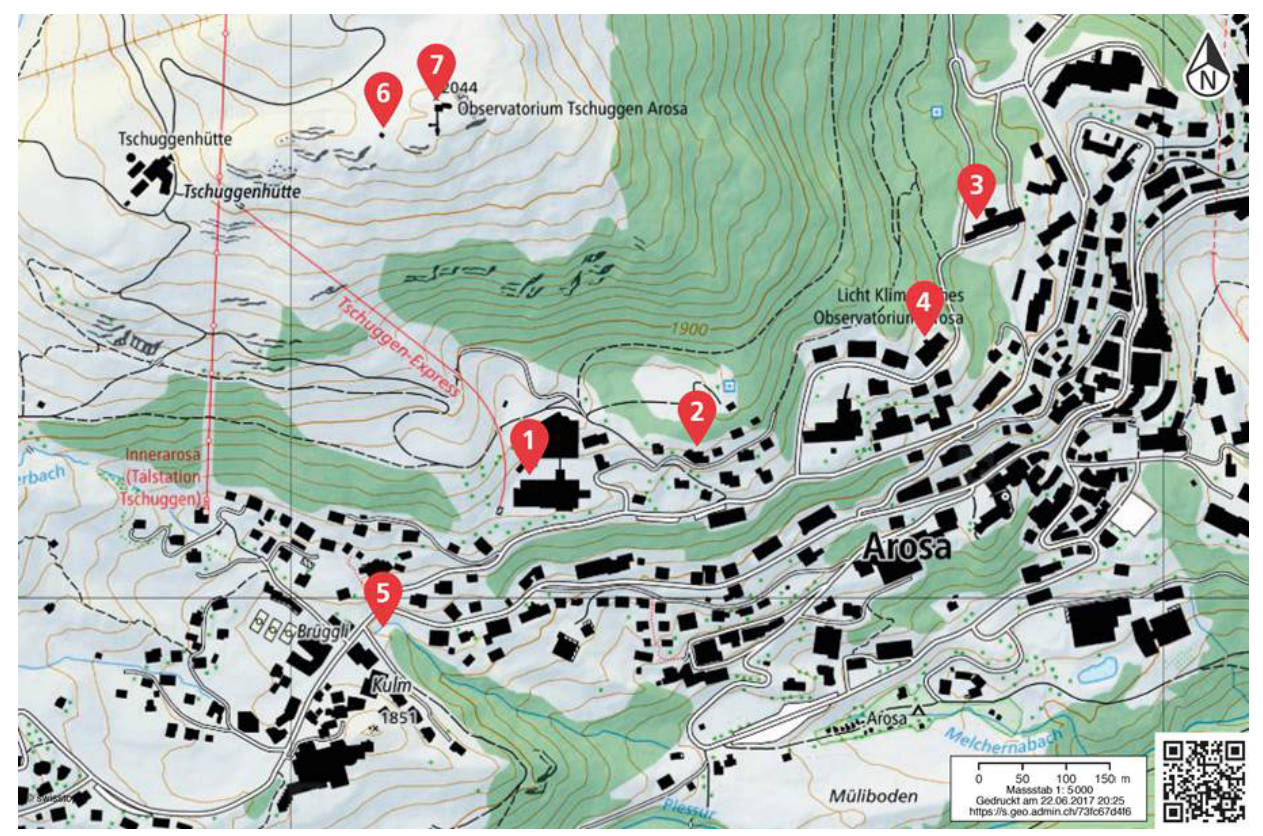

Figure 2. Map of important locations relevant to the Arosa Light Climatic Observatory (LKO). LKO measurement sites: (1) Sanatorium Inner-Arosa; (2) Villa Firnelicht; (3) Florentinum; (4) Haus zum Steinbruch. Other sites: (5) Götzbrunnen (a fountain named in honour of Götz); (6) the hut where Götz made his night-time measurements in Tschuggen; and (7) the astrophysical observatory at Tschuggen. Reproduced with permission from swisstopo (Swiss digital maps, geo.admin.ch).

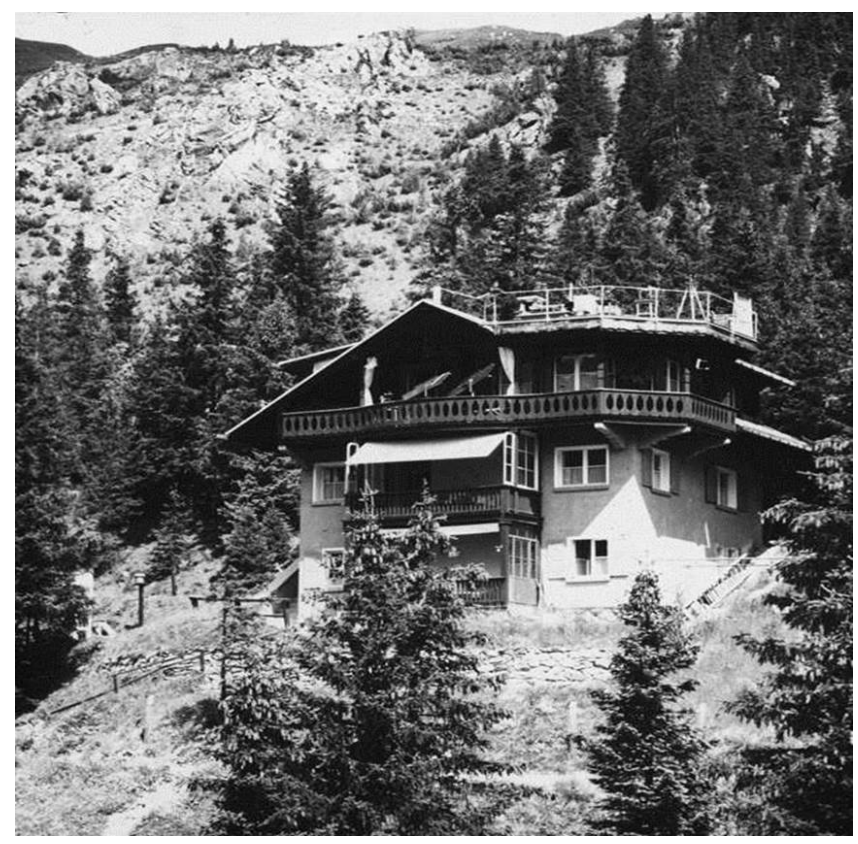

Figure 3. "Villa Firnelicht”, Götz's house in which the LKO, Götz's observatory, was hosted (see text).

Haensch company based in Berlin (Germany) to construct a Fabry-Buisson type of a sun spectrophotometer, with a design supervised by him. The instrument was delivered and used by Götz in his expedition to Svalbard (see below), but it is unknown to us why it was subsequently only rarely used. In 1926 Götz started a very fruitful collaboration with Gordon Dobson, a British physicist and meteorologist at the University of Oxford, who had just developed his first spectrophotometer (Walshaw, 1989). Götz began continuous total ozone measurements at Arosa using an instrument called a Fery spectrograph, which was developed by Dobson (Staehelin et al., 1998a). Later, Götz used improved sun spectrophotometers also constructed by Dobson (abbreviated as $D x$, where $x$ is the fabrication number; see Fig. 4). Dobson was very interested in the favourable climate and good weather and working conditions at the LKO. Thus, he arranged that the instruments were formally made available to the LKO through the International Association of Meteorology and Atmospheric Sciences (IAMAS, an association of the International Union of Geodesy and Geophysics (IUGG)). This allowed Götz to make total ozone observations at Arosa for many years, since it would have been very difficult for him to buy such spectrophotometers. After 1948 these instruments were formally borrowed through the International Ozone Commission (IO3C) of the IAMAS. The sun photometers constructed by Dobson measure the intensity of solar radiation at wavelength pairs in the range of 300$340 \mathrm{~nm}$ at the Earth's surface. Three different types of instruments were constructed by Dobson (Dobson, 1968) which are briefly characterised in Fig. 5. In order to minimise the falsifying effects of atmospheric aerosols on total ozone mea- 


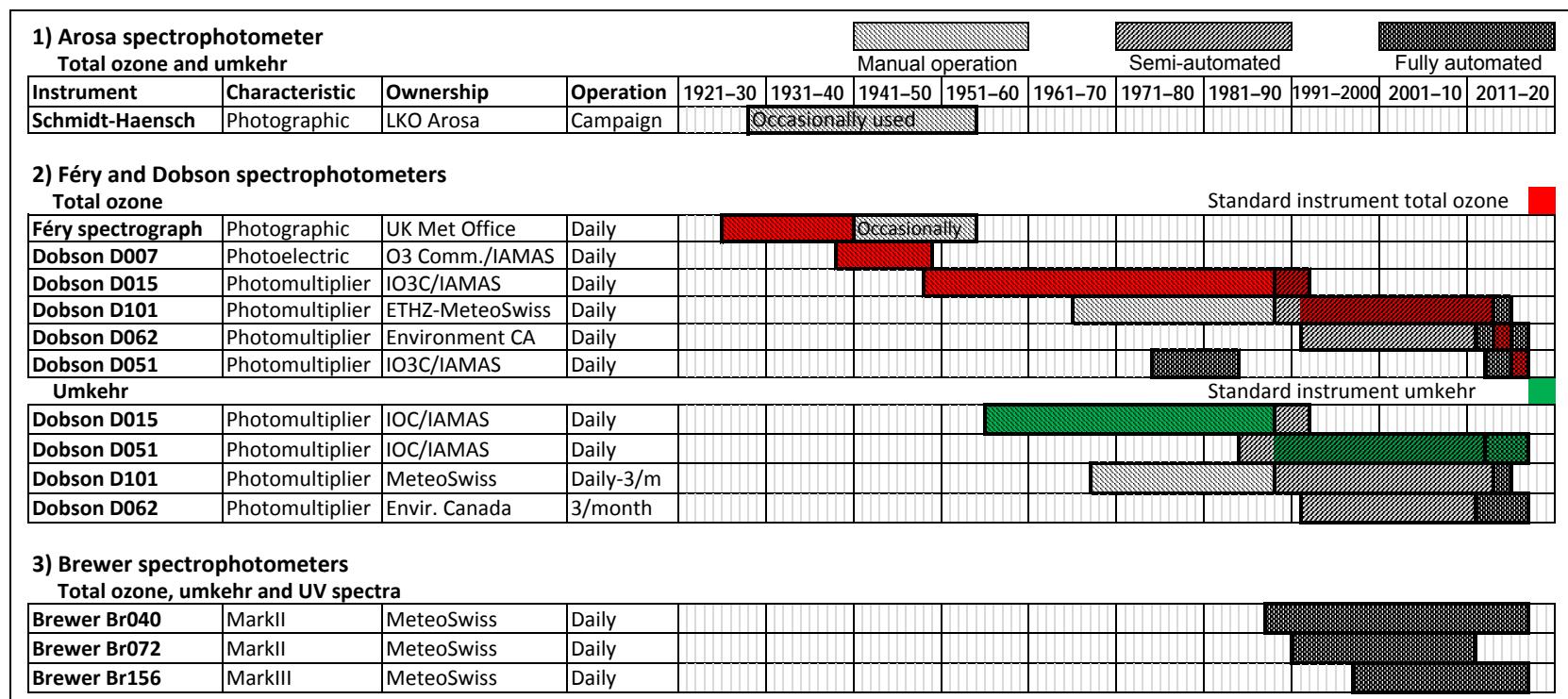

IO3C = International Ozone Commission / IAMAS= International Association of Meteorology and Atmospheric Sciences (earlier IAM)

Environment CA = Environment and Climate Change Canada / ETHZ = Swiss Federal Institute of Technology Zürich

Figure 4. Sun photometers used at LKO from 1926 to present. The "Arosa spectrophotometer" is a Fabry Buisson-type spectrograph built in 1926-1928 by the Schmidt-Haensch (Berlin) company from a design supervised by Götz. It was only occasionally used. Regular ozone measurements at LKO were instead made with instruments designed by Dobson. Initially, a photographic Féry spectrograph was used, while subsequent instruments were double monochromator spectrophotometers (detection: photoelectric or photomultiplier). The D101 instrument has been installed at Davos since January 2016. The Brewer spectrophotometers are single grating monochromator (Br40 and Br $72 \mathrm{MarkII}$ ) or double grating monochromator (Br156 MarkIII) systems. From November 2011-March 2013 Br72 was operated in Davos and again since June 2014. For more details see Staehelin and Viatte (2018).

surements, the two wavelengths pairs method was introduced during the International Geophysical Year (1958).

Götz became one of the leading ozone researchers. In the second half of the 1920s and the first half of the 1930s a key research question was how ozone is vertically distributed. Surface measurements e.g. from Arosa indicated low tropospheric ozone concentrations and rather unprecise measurements suggested ozone maxima in the mid-latitudes (in partial pressure) at altitudes of around 40-50 km (see Dobson, 1968). However, the Umkehr method developed by Götz et al. (1934) (see Fig. 5) showed maximum concentrations at $20-22 \mathrm{~km}$. This was considered a scientific breakthrough providing the first reliable information about the vertical ozone profile. This method is based on the "Umkehr effect", which Götz discovered during his expedition to Svalbard in 1929 (Götz, 1931). The first series of Umkehr measurements (aside from a limited number of observations made at Oxford in 1931) was performed together with Dobson and his coworker Meetham on the roof of the "Villa Firnelicht" in 1932/33 (Götz et al., 1934).

Götz was active in the international research community, as a member of the International Radiation Commission from 1932 to 1936 (Int. Rad. Com., 2008) and as a member of the International Ozone commission (IO3C) created in 1948, when it was formally established at the Seventh IUGG As- sembly, until 1954 (see Bojkov, 2012). Götz's research interests were broad, concerning many aspects of weather and climate, and led him to publish two books on focusing on the statistical analysis of radiation measurement and meteorological observations made at Arosa (Götz, 1926b, 1954).

During World War II, the KVV Arosa's financial support for the LKO was substantially decreased and Götz considered leaving Switzerland. Karl Wilhelm Franz Linke, professor and director of the Institute for Meteorology and Geophysics of the Goethe University of Frankfurt am Main (Germany) made him two offers to move to Frankfurt. At the same time Heinrich von Ficker, professor at the University of Vienna and director of the Central Institute for Meteorology and Geodynamics, asked Götz to become professor in Vienna (Austria). However, Götz decided to stay in Arosa (in the Swiss Alps). If he had moved to Frankfurt or Vienna during World War II, the column ozone measurements made at LKO would likely have come to an end after just about one decade of measurements.

During the 1930s economic depression, rich clients, who had been important to some of the sanatoria, no longer could afford to travel to Switzerland. Moreover, a few years after World War II, when modern antibiotics became available, the reasons for atmospheric studies related to tuberculosis therapy at LKO gradually became obsolete (Schürer, 2017). 
(a)

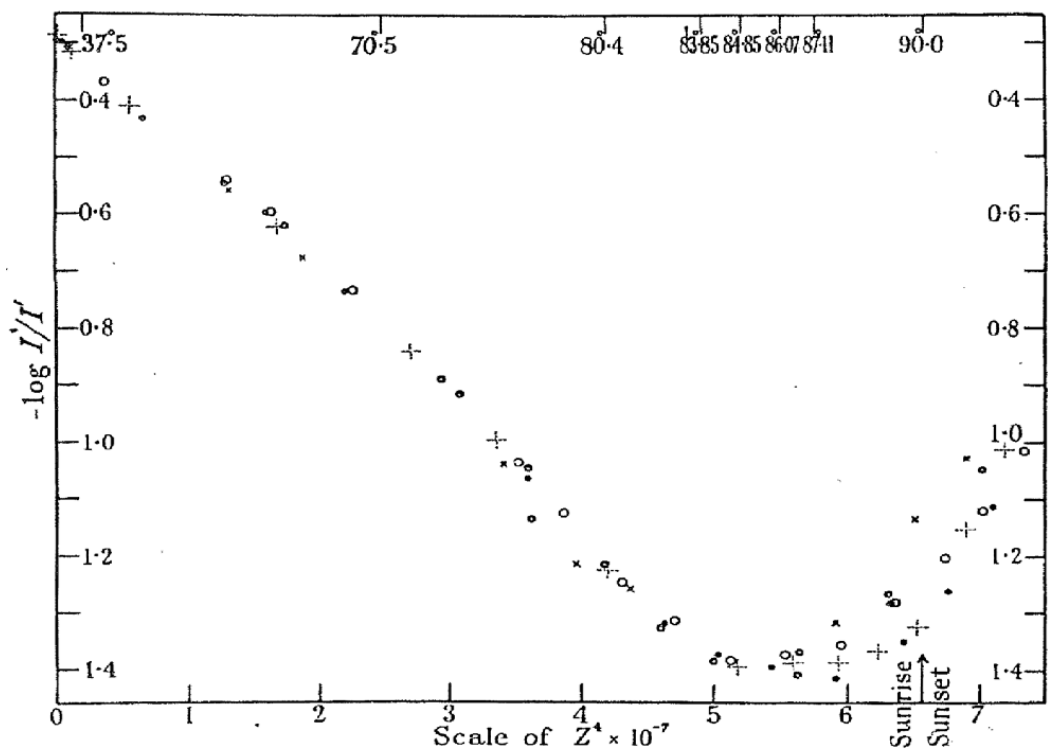

(b)

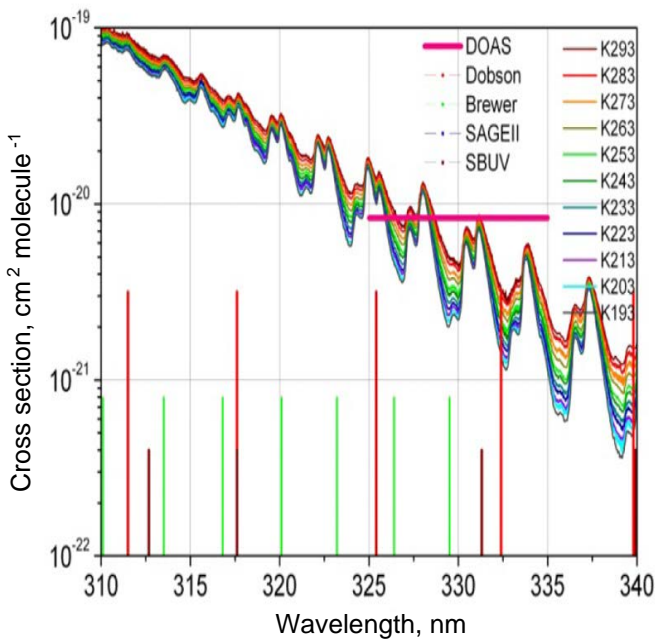

Fery spectrograph

(photographic detection)

3 wavelengths pairs:

306.2/326.4; 305.2/323.2;

$302.2 / 326.4$

Dobson instrument

(with photoelectric

detection)

311.0/330.0

(with photomultiplier)

A: $305.5 / 325.4$

B: $308.8 / 329.1$

C: $311.45 / 332.4$

D: $317.6 / 339.8$

since IGY (1958): AD

Figure 5. Ozone observations made using instruments designed by Dobson. (a) The Umkehr curve (Götz et al., 1934) used for ozone profile determination: zenith sky observation (determined by ozone absorption and scattering, wavelengths pair C) measured as a function of time covering sunrise or sunset (time represented by the solar zenith angle written at the top). When the sun reaches the lowest elevation angle the scattering at higher altitudes becomes predominant which causes the reversal (Umkehr). (b) Ozone absorption spectrum in the Huggins band (left, ACSO, 2015, Fig. 3) and wavelengths used in total ozone observation. AD wavelengths pairs used to minimise aerosol interference. The (World Primary) Dobson instrument is calibrated (extraterrestrial radiation) by the Langely plot method.

However, starting in the 1930s, Arosa was progressively promoted as a winter sport resort area. In November 1943, Götz provided a new justification for the measurements at LKO, proposing that the excellent air quality in Arosa was a "natural resource" and that such resort areas should quantify their air quality to obtain an objective grading (Götz, 1954). This proposal was part of a project for the "medical enhancement" of Switzerland's resort areas ("Medizinischer Ausbau der Kurorte"), which was termed "climate action" ("Klimaaktion") and funded by the Swiss Federal Office for Transport.
Through this project, Götz obtained support to study air pollution by making surface ozone measurements. He was convinced that high ozone concentrations were one characteristic of healthy alpine air, since at that time the (heavily) polluted urban air had low ozone concentrations (caused by the high city centre NOx emissions titrating ozone). After World War II, Götz significantly increased efforts to obtain additional support for research at LKO by applying for a wide range of grants, which allowed him to hire collaborators who assisted him with measurements and scientific work. 
In the last years of his life Götz suffered from health problems (including arteriosclerosis) (Trenkel, 1954) and he died at the age of 63 in 1954. Dr. Gertrud Perl was his main assistant from 1948 onwards and she continued making measurements even after Götz's death, but because of difficulties with Götz's wife, who owned "Villa Firnelicht" the LKO had to move to the Florentinum Sanatorium (see Fig. 2) at the end of 1953. Unfortunately, the Dobson instrument was damaged during transport to the Florentinum, so that there are a few months of data missing from the Arosa total ozone time series during this period.

\section{Period 1954-1962: first intermediate period}

After Götz's death, it was uncertain for several years whether the measurements at LKO would continue. Jean Lugeon, the director of MeteoSwiss (Meteorologische Zentralanstalt at the time), supported the ozone measurements at Arosa during this critical period. He knew Götz personally, since they had taught together at the University of Zürich, and was aware of the scientific value of the measurements. He was also the coordinator of the Swiss contribution to the International Geophysical Year (IGY) in 1958, in which the total ozone measurements at Arosa were recognised as a geophysically significant data set. For a few years, the Swiss National Science Foundation (SNSF) contributed to Perl's salary in addition to the support received from the KVV Arosa, the Arosa municipality and the canton Grisons. From 1957 onwards, the Arosa total ozone measurements were additionally supported by MeteoSwiss. Hans-Ulrich Dütsch, a former graduate student of Götz (see Sect. 4.1), also played an important role for the continuation of ozone measurements at Arosa. He wrote a letter to the head (minister) councillor of the Swiss Federal Department of Home Affairs in Bern. In his response we read that MeteoSwiss could be mandated to assume the responsibility for the Arosa ozone measurements based on several resolutions of the World Meteorological Organization (WMO), which advised that national meteorological services undertake ozone measurements. It was suggested that the Federal Meteorological Commission ("Eidgenössische Meteorologische Kommission"), the committee responsible for overseeing MeteoSwiss, should consider this in a comprehensive way, also looking at additional options, such as moving the LKO measurements to nearby Davos. Dütsch disagreed with the move to Davos, as he feared that this might lead to a serious discontinuity in the ongoing Umkehr measurements that were started in 1956 by Dütsch (see Sect. 4.2), because of larger aerosol contamination in Davos. In the end, the LKO stayed independent and was not integrated into MeteoSwiss, but MeteoSwiss and KVV Arosa provided financial support and measurements were continued at Arosa.

\section{Period 1962-1985: Hans-Ulrich Dütsch}

\subsection{Dütsch and international ozone science}

After Dütsch (Dütsch, 1946) completed his $\mathrm{PhD}$ thesis in 1946 (Photochemical theory of atmospheric ozone under consideration of non-equilibrium states and airflow), he first worked as a physics teacher (mainly) at a high school (Gymnasium) in Zürich. However, he remained interested in ozone research and eventually decided to pursue a career in science (see Fig. 6). From 1962-1965 he lived with his family in Boulder (Colorado, USA) working as a researcher at the newly founded National Center for Atmospheric Research (NCAR). Together with Carl Mateer, Dütsch was the first to use modern computers to retrieve vertical ozone profiles with the Umkehr method.

In 1965 Dütsch was appointed as full professor at the ETH Zürich (ETHZ), where he served as director of the Laboratory of Atmospheric Physics (LAP, merged in 2001 with the Institute of Climate Sciences to become today's Institute for Atmospheric and Climate Science (IAC)). Dütsch's research continued to focus on ozone, and he continued, pursued and extended the Swiss ozone measurements (see Sect. 4.2).

During Dütsch's first years at ETHZ the main motivation for atmospheric ozone measurements at Arosa and Payerne was improving understanding of the "high atmosphere" circulation patterns with the aim of providing improved weather forecasts. Publications using measurements from the nearby Hohenpeissenberg Observatory (located in Bavaria, Southern Germany) revealed links between ozone levels and synoptic weather types (Hartmannsgruber, 1973; Attmannspacher and Hartmannsgruber, 1973, 1975) and the relationship between the vertical distribution of ozone and synoptic meteorological conditions became an important research topic in the 1960s and the early 1970s (see Breiland, 1964).

Stratospheric ozone depletion resulting from anthropogenic emissions was first publicised in the 1970s. Molina and Rowland (1974) as well as Stolarski and Cicerone (1974), independently discovered that chlorine radicals destroy stratospheric ozone in a chain reaction. Furthermore, Molina and Rowland postulated that chlorofluorocarbons were a possible source gas for stratospheric chlorine. The chemical industry, particularly market leader DuPont, strongly objected to the view of Molina and Rowland. DuPont went so far as to launch an advertisement in the New York Times in 1975 stating that "Should reputable evidence show that some fluorocarbons cause a health hazard through depletion of the ozone layer, we are prepared to stop production of the offending compounds". This provided a new justification for making high-quality total ozone measurements, namely as a basis for reliable long-term trend analysis. This was a new challenge for ground-based total ozone measurements, as stratospheric ozone in the extratropics can vary by as much as $\pm 20 \%$ from day to day, whereas 
anthropogenic stratospheric ozone changes were (and still are) on the order of only a few percent per decade.

Dütsch was one of the few scientists making important contributions to ozone research both before and after the debate on anthropogenic ozone depletion had started. Prior to this, Dütsch was largely curiosity-driven and had been interested in better understanding stratospheric ozone climatologies. For example, Dütsch (1974) provided basic science later served to validate numerical simulations of anthropogenic ozone depletion. He also contributed to the IO3C, serving first as member from 1957 to 1961 , and then as secretary for 15 years (1961-1975), before being elected as president (1975-1980), and being named an honorary member in 1984. He was also the main organiser of two important ozone symposia (the Quadrennial Ozone Symposia, organised by the IO3C) that took place in Arosa in 1961 and 1972. For more information on Dütsch's research, see also Staehelin et al. (2016).

\subsection{Ozone measurements at LKO under Dütsch}

In 1956, Dütsch was able to find resources to ensure the Umkehr ozone measurements in Arosa continued on a regular, operational basis. When Gertrud Perl had to leave Arosa in 1962 because of health problems, Dütsch took the responsibility and scientific leadership of the LKO, although he was still living in Boulder (CO, USA) at the time. A large majority of the observations, particularly the Umkehr measurements, were performed by students, under the tutelage of Perl and others, until Kurt Aeschbacher became responsible for the LKO measurements in 1964, remaining so until November 2001. When Dütsch became professor at ETHZ in 1965, financial support for the measurements at LKO (total ozone and Umkehr) continued as before (i.e. via KVV Arosa, Arosa municipality and the Canton Grisons). In addition to the spectrophotometric measurements, Dütsch also initiated ozone sonde measurements, which made it possible to observe ozone vertical profile in more detail. In 1966/67, these balloon measurements were operated by Dütsch from Kilchberg (close to Zürich), but in August 1968 MeteoSwiss took over these observations and made them from Payerne, $140 \mathrm{~km}$ south-west of Zürich on the Swiss plateau (Jeannet et al., 2007). In 2008 Payerne became a member of "The Global Climate Observing System (GCOS) Reference Upper-Air Network" (GRUAN) (fully certified in 2015), an international observing network under the auspices of WMO. GRUAN aims at measuring essential climate variables providing long-term, high-quality climate data records from the surface, through the troposphere, and into the stratosphere.

When Dütsch was responsible for the LKO, total ozone and Umkehr measurements were routinely performed using two Dobson spectrophotometers (see Fig. 4). To obtain the total ozone, only direct sun observations were performed. Dütsch applied the statistical Langley plot method to update the instrumental constants of the Dobson instruments every year (Dütsch, 1984). To apply the statistical Langley plot method (which was also used by Farman et al., 1985) a large number of ozone observations with different solar angles is required and therefore the observers need to choose suitable meteorological conditions, e.g. cloud free conditions lasting for at least several minutes. Each year Dütsch went to Arosa for several days to check all the total ozone measurements for reliability and to apply the statistical Langley plot method. This led to small corrections being made to the total ozone measurements for the previous year and some small changes to the instrumental constants for the following year. Students, who usually stayed in Arosa for several months at a time, made the Umkehr measurements, which need to be started prior to sunrise every morning (see Fig. 5).

In 1973, the LKO measurements were moved from the "Florentinum" to "Haus Steinbruch" (see Fig. 2), just a few hundred metres away. The working conditions at the LKO were much better at "Haus Steinbruch" than at the "Florentinum"; however, the running costs were higher (for more detail see Staehelin and Viatte, 2018). In 1978, the first international inter-comparison campaign of Dobson spectrophotometers took place in Arosa. This was organised by Dütsch under the auspices of the WMO. The results of this first inter-comparison exercise at Arosa were not satisfying as "differences between (standard) instruments led to a debate as to which should be used as the standard for the intercomparison" (see Staehelin et al., 1998a). However, this debate deepened the insight into how necessary such comparisons were (and still are), fostering the excellent reputation of Swiss ozone research. As a result of these discrepancies Dütsch continued to apply the statistical Langley plot method to update the instrumental constants up to the beginning of the 1990s.

\section{Period 1985-1988: second intermediate period}

\subsection{International development and the importance of the Arosa total ozone time series}

In the early 1980s, as new information about ozone chemistry reaction rate constants became available, it seemed that chemical ozone depletion by ODSs was considerably lower than had been predicted in the late 1970s (Benedick, 1991). However, in 1985 the Antarctic ozone hole was discovered (Farman et al., 1985) and the international ozone research community was able to demonstrate that the ozone hole was caused by the chlorine and bromine in halocarbons, which were largely of anthropogenic origin. New insight came through the discovery that the chlorine and bromine species are very efficiently converted into ozone destroying forms on the surface of polar stratospheric cloud particles (Solomon et al., 1986), acting as efficient catalysts in the cold polar stratospheric vortex (for reviews see Rowland, 1991; Peter, 1997; Solomon, 1999). 


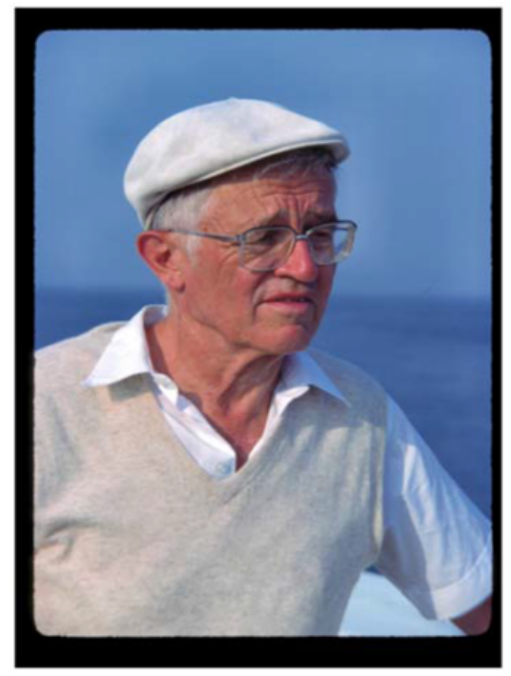

Hans-Ulrich Dütsch

$\begin{array}{ll}1917 & \begin{array}{l}\text { Born on 26 Oct. in Winterthur (Switzerland) } \\ \text { Childhood in Winterthur } \\ \text { Diploma in theoretical physics with a minor in } \\ \text { meteorology, University of Zürich }\end{array} \\ 1940 & \begin{array}{l}\text { Graduate student of Götz } \\ 1943-1946\end{array} \\ 1947-1962 & \begin{array}{l}\text { High school (Gymnasium) teacher in physics in Zurich, } \\ \text { continuing ozone research } \\ \text { Visiting scientist at the Massachusetts Institute of } \\ \text { Technology, MIT, USA }\end{array} \\ 1960-1964 & \begin{array}{l}\text { Researcher at the High Altitude Observatory in Boulder } \\ \text { (CO, USA) }\end{array} \\ & \begin{array}{l}\text { Head of the Ozone Research Program at the newly } \\ \text { founded NCAR (CO, USA) }\end{array} \\ \text { Prof. at the Swiss Federal Institute of Technology Zürich } \\ \text { (ETH Zürich) } \\ \text { Died on 27 Dec. in Zürich (Switzerland) }\end{array}$

Figure 6. Biography of Hans-Ulrich Dütsch.

In the mid-latitudes, the first analysis based on the relatively short record of measurements from the Total Ozone Mapping Spectrometer (TOMS) instrument on-board the Nimbus 7 satellite available at the time also showed rapid ozone decline (Heath, 1988). However, ground-based total ozone measurements such as those made using Dobson instruments did not confirm the large downward trends suggested by the satellite data. This discrepancy led to the 1988 publication of the International Ozone Trend Panel report (IOTP, 1988). The report demonstrated that TOMS data available at the time were not reliable enough for trend analysis because of inappropriate treatment of the degradation of the diffuser plate. Later these data were reanalysed more extensively using additional wavelengths in the retrieval algorithms and results were significantly improved (Stolarski et al., 1991). It turned out that also some of the data from the ground-based instruments were not of high enough quality to carry out reliable long-term trend analyses. This was attributed to calibration issues with the Dobson instruments, which showed frequent sudden changes when compared to TOMS overpass data (IOTP, 1988). Rumen Bojkov, Secretary of the IO3C (1984-2000), used TOMS data to provide "provisionally revised" ground based measurements, which had weaknesses such as not correcting for sulfur dioxide $\left(\mathrm{SO}_{2}\right)$ interferences leading to potential errors in ozone trends based on Dobson series (e.g. De Muer and De Backer, 1992).

The most important application of the long-term measurements from Arosa (see Fig. 7) was probably their use in the 1988 IOTP report. The Arosa time series was the only Dobson dataset that required no correction and was much longer than any of the other ground-based measurement records. Results from Neil Harris's PhD thesis were published in the IOTP and showed, for the first time, significant decreases in stratospheric ozone in the northern mid-latitude winter season (Harris, 1989). He used two different approaches, namely (1) dividing the individual records into two periods of similar length using measurements going back to 1957 and (2) developing a novel multiple linear regression model taking into account trends for different months. In this model the downward trend started in 1970, and the analyses also showed that the negative trend was not sensitive to the start year. At present, standard Dobson measurements are based on observations of two $(\mathrm{AD})$ wavelength pairs, which allow to minimise the interference by aerosols, a technique introduced during the International Geophysical Year (IGY) in 19571958 (cf. Fig. 5). To further support his main conclusion, Harris (1989) also used a set of different wavelength pair data (C, see Fig. 5b) from Arosa, which are available as representative (homogenised) measurements since 1931. Again, he found similar negative total ozone trends as at most other sites in the northern mid-latitudes (IOTP, 1988).

\subsection{Continuation of measurements at the LKO}

After Dütsch's retirement in 1985, the continuation of Swiss long-term ozone measurements again became uncertain. The professor succeeding Dütsch focused on another research topic and consequently the ETH Zürich argued that the continuation of operational ozone measurements did not fall under the responsibility of a university. Conversely, MeteoSwiss, which already was responsible for the ozonesonde measurements since 1968, argued that such long-term measurements needed scientific analysis by a well-qualified scientist, which MeteoSwiss was not able to support (a hiring freeze for permanent positions existed at the federal level at the time). Dütsch again wrote a letter to the responsible minister of the Federal government to point out the importance 


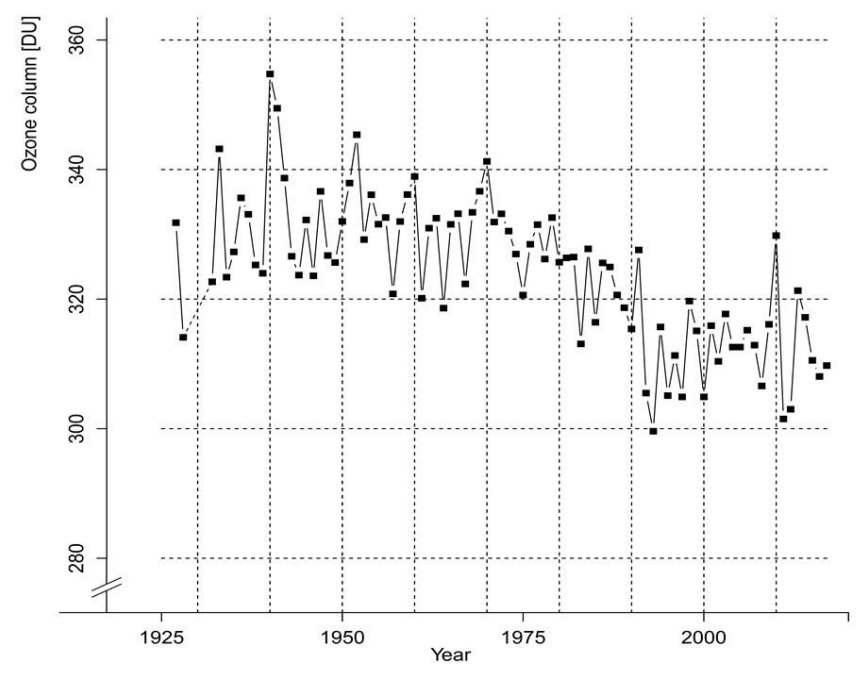

Figure 7. Annual mean total (column) ozone values measured at the world's longest continuous spectrophotometer site in Arosa, Switzerland, from 1926 to 2017. The ozone column in Dobson units, where $100 \mathrm{DU}$ correspond to a $1 \mathrm{~mm}$ thick slab of pure ozone gas at standard conditions $(273.15 \mathrm{~K}, 1000 \mathrm{hPa})$.

of the Arosa ozone measurements. Representatives from the Swiss Federal Office for the Environment (the "Swiss EPA") argued that ozone research in Switzerland needed to be continued since expert ozone researchers served a vital role in providing advice to policy makers regarding both stratospheric (in terms of the Vienna Convention and Montreal Protocol) and tropospheric ozone. Subsequently, a commission of the Swiss Academy of Natural Sciences was tasked with analysing the situation. Government representatives as well as Swiss ozone researchers were invited to their meeting. Again, it was considered whether it made sense to move the LKO measurements to Davos (PMOD), but no decision was made in this regard. Nevertheless, MeteoSwiss and ETH Zürich (i.e. IAC, Institute for Atmospheric and Climate Science since 2001, at that time Laboratory of Atmospheric Physics (LAPETH)) agreed to continue the measurements, with the former officially accepting to take responsibility for the continuation of the ozone measurements at Arosa (total ozone and Umkehr) as well as the ozonesondes launched from Payerne, and the IAC at ETH Zürich consenting to continue ozone research. The agreement - implying that the person responsible for the LKO operations was moved to a MeteoSwiss position, whereas the IAC filled a scientific position with a major focus on ozone research - became effective at the beginning of 1988 .

\section{Period 1988-2014: ozone measurements and research at MeteoSwiss and IAC (ETHZ)}

\subsection{International development: the Montreal Protocol}

Since 1988, the most important justification for ozone measurements at LKO Arosa (total ozone und Umkehr) and ozone sonde launches in Payerne has been the documentation of the effect of ODSs on the stratospheric ozone layer and the effectiveness of the Montreal Protocol. Chemical ozone depletion by ODSs is expected to evolve very similar to the evolution of Equivalent Effective Stratospheric Chlorine (EESC). EESC provides an estimate of the total amount of halogens in the stratosphere, calculated from emission of chlorofluorocarbon and related halogenated compounds into the troposphere (lower atmosphere) and their efficiency in contributing to stratospheric ozone depletion (hence "effective"), and by taking the higher ozone destructiveness of bromine appropriately into account (hence "equivalent"). EESC peaked in the second half of the 1990s and subsequently showed a slow decrease, which is attributable to the Montreal Protocol but its slowness is dictated by the long lifetimes of the emitted substances (see Fig. 8a). Total ozone measurements at Arosa are broadly consistent with long-term evolution of EESC (Staehelin et al., 2016) showing record low values in the early 1990s (Fig. 8b, cf. Fig. 7). The recovery of the ozone layer is a slow process and the signs of any sort of turnaround in the Arosa total ozone time series are still indistinct. Figure $8 \mathrm{~b}$ shows the large interannual variability of the annual means, which is normal for a single measurement station and renders an attribution of the change in the downward trend difficult. While the modelled results suggest that the Montreal Protocol and its amendments and adjustments have helped to avoid millions of additional skin cancer cases, Fig. $8 \mathrm{~b}$ indicates that the global network of ozone station measurements needs to remain strong in order to achieve a clear detection of the trend reversal and a proper attribution of the reasons.

\subsection{LKO and related activities}

\subsubsection{Cooperation between MeteoSwiss and IAC (ETHZ)}

The cooperation between MeteoSwiss and the IAC of ETH Zürich ensured that the different strengths of the two institutions were fully utilised. MeteoSwiss had the expertise and resources to renew the infrastructure at the Arosa station and was also able to guarantee reliable long-term operation through permanent contracts for technicians and scientists. On the other hand, IAC (ETH Zürich) had the opportunity to lead scientific research, for example, with $\mathrm{PhD}$ theses that produced results published in the scientific literature. The use of ozone measurements as basis for scientific research requires high-quality data and the results from the ETH studies 


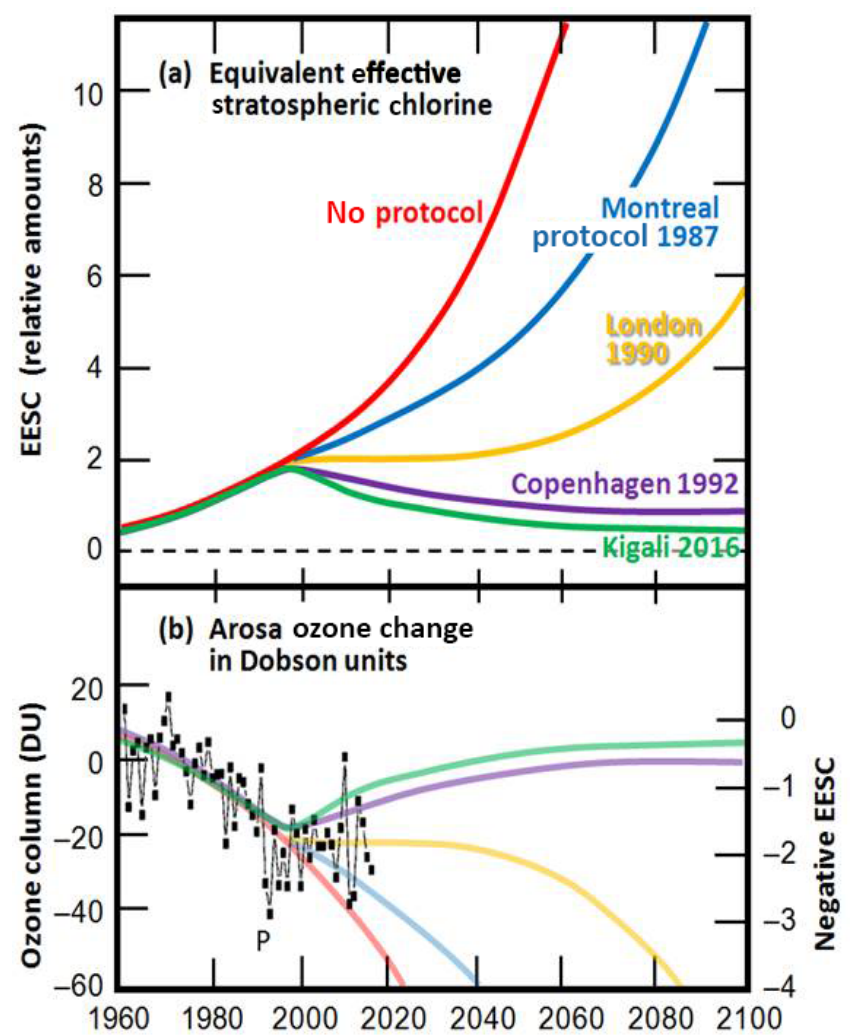

Figure 8. (a) Relative abundance of ozone-depleting substances (ODSs, i.e. volatile halocarbons) expressed as equivalent effective stratospheric chlorine (EESC) for the mid-latitude stratosphere, shown for various scenarios (demonstrating the impact of the Montreal Protocol and its subsequent Adjustments and Amendments). EESC can be viewed as a measure of chemical ozone depletion by ODSs and takes into account the temporal emission of the individual ODS species as well as their ozone depleting potential. (b) Arosa annual mean ozone columns (black symbols, as in Fig. 7) in comparison with the scenarios in panel (a). "P" marks the eruption of Mt. Pinatubo in 1991, which has aggravated the ozone loss.

thus provided both a feedback mechanism in terms of data quality and enhanced visibility of the ozone measurements.

\subsubsection{Renewal of the LKO infrastructure}

When Meteoswiss become responsible for the LKO ozone measurements in 1988, the instrument infrastructure required renewal and extension. This was completed under the leadership of Bruno Hoegger and included constructing a spectrodome to house the two Dobson spectrophotometers as well as semi-automation of the Dobson total ozone measurements and full automation of the Dobson Umkehr measurements (Hoegger et al., 1992). Three Brewer instruments were also purchased between 1988 and 1998, thus allowing increased reliability of the Arosa total ozone series by complementing the Dobson Umkehr measurements and by providing instrumental redundancy (see Fig. 4). Furthermore, UVB measure- ments were added. For more technical information including new electronics see Staehelin and Viatte (2018). Stübi et al. (2017a) demonstrated the excellent stability of the Arosa Brewer triad over the past 15 years.

\subsubsection{Homogenisation of the Arosa total ozone and Umkehr time series}

The Dobson instrument D15 was the main instrument used to measure total ozone in Arosa from 1949 to 1992 (see Fig. 4). Archie Asbridge (formerly of Atmospheric Environment Canada) inspected this instrument after it was taken out of service in 1992 and it turned out that it had been operated in optical misalignment. Using the overlap between total ozone measurements of the D15 and D101 instruments, the latter of which was calibrated against the world standard instrument in 1986 and again in 1990, the Arosa column ozone time series was adjusted to the scale of the world primary Dobson instrument (for more detail see Staehelin et al., 1998a; Scarnato et al., 2010). The Arosa Umkehr time series also required homogenisation (Zanis et al., 2006).

\subsubsection{Foci of scientific studies since the 1990s}

The comparison of the unique Arosa total ozone time series from Dobson and Brewer instruments has allowed studies of the differences between the two instrument types (Staehelin et al., 1998a; Scarnato et al., 2009, 2010) as well as their long-term behaviour as they are calibrated in different networks. The large data set of quasi-simultaneous measurements was particularly valuable for studying the effect of temperature dependence of ozone absorption cross-sections on total ozone measurements attributable to the different wavelengths used in Dobson and Brewer instruments (Scarnato et al., 2009; Redondas et al., 2014). These results were an important contribution to the GAW ACSO (Absorption Cross-Sections of Ozone) project in which available laboratory cross-sections of atmospheric ozone measurements were studied (ACSO, 2015; Orphal et al., 2016).

In the 1990s, quantification of the downward ozone trends was the main reason for making long-term stratospheric measurements (comp. Sect. 5.1, and Staehelin et al., 1998b, 2001). These trends were seen as a consequence of increasing ODS concentrations. Subsequent studies were also devoted to understanding the potential contribution of other processes enhancing the observed downward trends, including long-term climate variability, e.g. related to tropopause altitude (Steinbrecht et al., 1998) and climate patterns (Steinbrecht et al., 2001). The unique length of the Arosa total ozone series was very valuable in demonstrating that the North Atlantic Oscillation (NAO) or Arctic Oscillation (AO) enhanced downward winter ozone trends in central Europe for the period up to the mid1990s (Appenzeller et al., 2000; Weiss et al., 2001). Brönnimann et al. (2004a, b) also showed that the record high values of total ozone at Arosa that oc- 
curred in the early 1940s were due to an increase in strength of Brewer-Dobson circulation caused by a very large El Niño Southern Oscillation anomaly during that period.

The unique length and high-quality of the Arosa total ozone and Umkehr measurements also meant they were important for the EU project CANDIDOZ (Chemical and Dynamical Influences on Decadal Ozone Change; Zanis et al., 2006; Brunner et al., 2006; Harris et al., 2008). Later, as the ODS concentrations have decreased, documentation of the "turn around" in stratospheric ozone trends became more and more important (e.g. Mäder et al., 2010). The Arosa time series was also used to introduce the concept of extreme value theory in ozone science (Rieder et al., 2010a, b). This allowed attribution of extreme ozone values to events of various origins, dynamical features such as ENSO or NAO or chemical factors, such as cold Arctic vortex ozone losses, or major volcanic eruptions of the 20th century, e.g. Mt. Pinatubo.

\subsubsection{Tropospheric ozone}

The surface ozone measurements from Arosa are unique and very valuable for tropospheric chemistry studies. Surface ozone measurements were begun already in the 1930s by Götz to quantify the contribution of tropospheric ozone to the total column, and were later continued by the careful and representative surface ozone measurements made in the 1950s (Götz and Volz, 1951; Perl, 1965). Thanks to these measurements it was possible to show that surface ozone concentrations increased by more than a factor of two from the 1950s to 1990 (Staehelin et al., 1994). This has commonly been attributed to the large increase in ozone precursor emissions (nitrogen oxides, volatile hydrocarbons, and carbon monoxide) resulting from the strong economic growth in industrialised countries following World War II. The surface ozone measurements made at Arosa and Jungfraujoch were pillars in the studies of Parrish et al. (2012, 2013), which contributed to an important report by the Task Force of the Hemispheric Transport of Air Pollution (HTAP). HTAP was organised in 2005 under the auspices of the United Nations Economic Commission for Europe (UNECE) Convention on Long-range Transboundary Air Pollution (LRTAP Convention) to study intercontinental transport of ozone in northern mid-latitudes. Based on these data, Parrish et al. (2014) compared three state of the art chemistry climate models (CCMs) to show that simulated surface (baseline) ozone trends over Europe were about a factor two smaller than those seen in the available observations. This result was recently confirmed by Staehelin et al. (2017).

\section{Future of ozone measurements at the LKO}

\subsection{International demands}

Policy makers and the general public would like to see proof of the effectiveness of the Montreal Protocol and to better understand how climate change will affect the ozone layer, i.e. what are the impacts of the stratospheric cooling and the anticipated enhanced Brewer-Dobson circulation on ozone, and what this means for polar, mid-latitude and tropical ozone.

Recovery of the stratospheric ozone layer in response to the reduction of ODS concentrations controlled by the Montreal Protocol is slow (see Sect. 6.1) and requires continued long-term stratospheric ozone observations. ODSs most directly impact ozone in the upper stratosphere, where photolysis leads to the release of halogen radicals from these species. Extensive data analyses carried out under the auspices of the SI2N activity commonly sponsored by SPARC (Stratosphere-troposphere Processes and their Role on Climate), IO3C, IGACO-O3/UV (Integrated Global Atmospheric Composition Changes), and NDACC (Network for Detection of Atmospheric Composition Changes) highlighted issues related to the availability and uncertainty of measurements. Recent examples are merged satellite datasets and trend analysis techniques (see the special journal issue jointly organised between Atmospheric Chemistry and Physics, Atmospheric Measurement Techniques, and Earth System Science Data: Changes in the vertical distribution of ozone - the SI2N report). Steinbrecht et al. (2017) presented a recent analysis of upper stratospheric ozone trends confirming the expected increase in upper stratospheric ozone in extratropics. Finally, Ball et al. (2018) showed that total ozone in the mid-latitudes has not increased as expected and their careful analysis of mostly satellite measurements indicated a downward trend in the lower stratosphere (15-22 km) which continued since 1987. The physical cause of this surprising trend is presently unknown and requires further study.

It is vital to continue high-quality stratospheric ozone measurements to be able to follow the slow recovery of the ozone layer in response to the changing burden of stratospheric ODSs, including nitrous oxide $\left(\mathrm{N}_{2} \mathrm{O}\right)$, which is likely to become the dominant species for stratospheric ozone depletion in future (Ravishankara et al., 2009; Portmann et al., 2012).

Climate change will modify the distribution of stratospheric ozone in different ways (see e.g. Arblaster et al., 2014). Increasing greenhouse gases cause decreasing stratospheric temperatures, which in turn modify reaction rates and lead to increasing extratropical stratospheric ozone concentrations. This is not the case over the poles, where the stratosphere is not expected to cool on average. Furthermore climate change is expected to enhance the Brewer-Dobson circulation which transports ozone from the main tropical production region to the extratropics (Butchart, 2014). Modification of the Brewer-Dobson circulation is expected to increase 


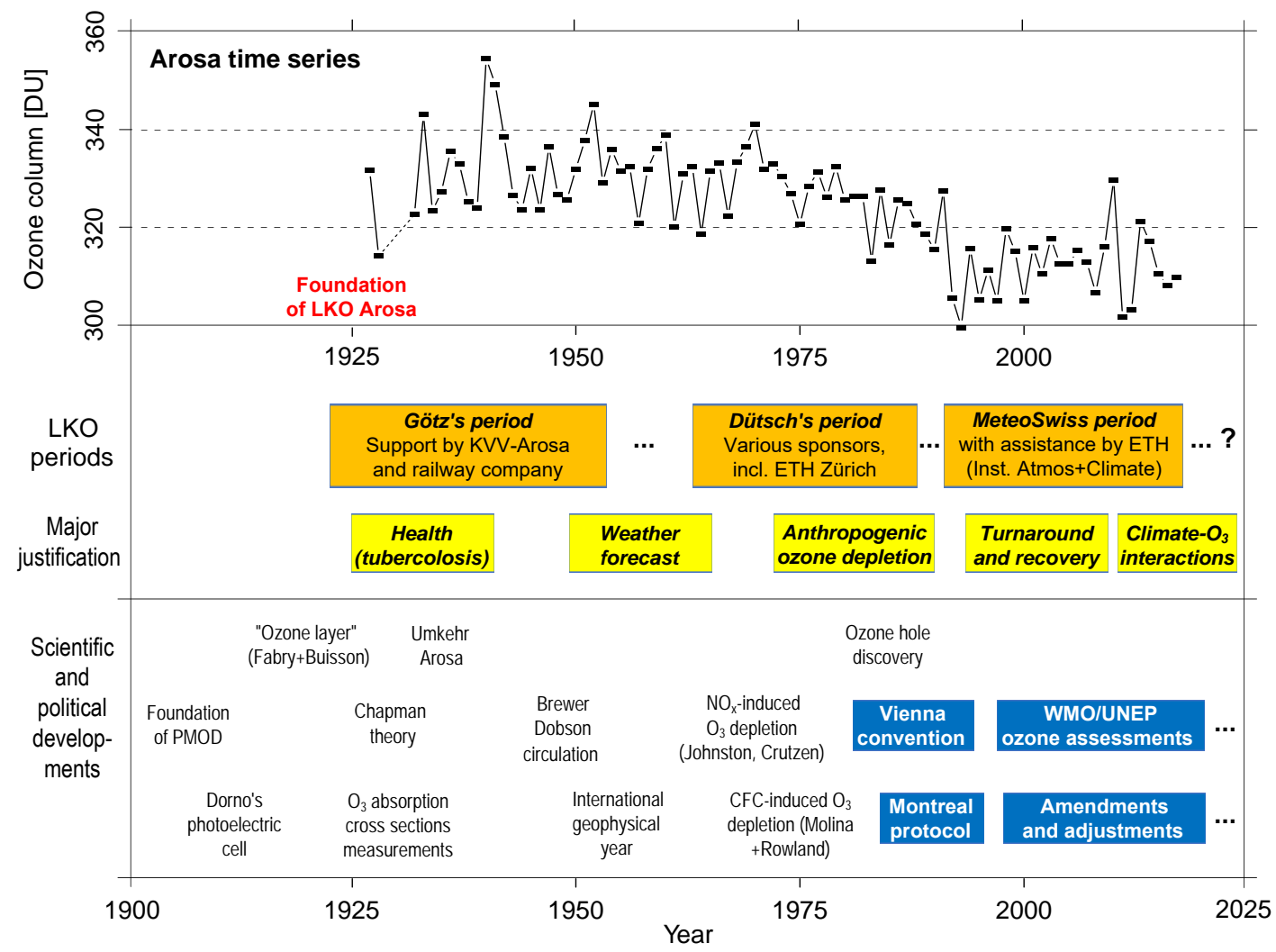

Figure 9. Historical overview of the successive periods of the Light Climatic Observatory of Arosa (LKO). Total ozone measurements (top, annual means); different phases during the history of LKO including main sponsors (in orange); justification of measurements for society (in yellow); milestones in international ozone research and international legislation (blue).

stratospheric ozone in the mid-latitudes to levels above those seen in the past; this has been termed "super recovery". In contrast, the enhanced transport out of the tropics is expected to result in a decrease in stratospheric ozone in these regions. However, the enhancement of the Brewer-Dobson circulation is still under debate, with state-of-the-art CCMs projecting an increase but only controversial observational evidence being available. Importantly, the expected enhancement depends strongly on the climate change scenario investigated, thus it is essential that high-quality measurements are continued.

The unique length of the Arosa time series is particularly useful for documenting the effects of climate change on ozone since the dataset covers a period of almost 40 years when the stratosphere was relatively undisturbed by anthropogenic influence, about 25 years in which anthropogenic ODSs increased in concentration in the stratosphere, and the latest period with the slow decrease in stratospheric ODS concentrations. The Arosa time series will therefore play a crucial role in the coming decades to further document ozone changes in the northern mid-latitudes, including the predicted "super recovery" expected to become important around 2030 (e.g. Hegglin et al., 2015).

\subsection{Continuation of measurements at the LKO}

The MeteoSwiss board of directors decided in 2015 to explore the possibility of moving the Arosa measurements to the PMOD in Davos. Such a move would result in reduced measurement costs in combination with the advantage of the excellent technical infrastructure and expertise that is available at the PMOD in Davos. Within this activity the Dobson instruments are currently completely automated (comp. Fig. 4). However, before such a move is to take place, a multiannual period of overlapping measurements at both sites (Arosa and Davos) is essential. A break in the world's longest total ozone time series would be very unfortunate. A relocation is particularly challenging as stratospheric recovery from ODS is expected to be slow (see Sect. 6.1) meaning ozone changes will be small, and thus very high-quality (i.e. very high-stability) measurements are required. At present simultaneous total ozone measurements of Brewer instruments of Davos and Arosa have been analysed and presented (Stübi et al., 2017b). 


\section{Summary and conclusions}

Homogenous long-term records, such as the total ozone record from Arosa, are very valuable for trend analyses in climate science. Reliable long-term, ground-based total ozone measurements are also crucial for validation of ozone observations from space, particularly in terms of validating the long-term stability of merged satellite datasets (e.g. Labow et al., 2013). Furthermore, they serve as a baseline for evaluating numerical simulations such as chemistry-climate models (CCMs), which are used to make projections of future ozone evolution (see e.g. Eyring et al., 2013; Arblaster et al., 2014). The extraordinary length of the Arosa record was important for a wide range of studies, including the analysis of stratospheric ozone related to long-term climate variability such as the NAO/AO (Appenzeller et al., 2000) and El Niño Southern Oscillation (Brönnimann et al., 2004a, b). Furthermore, the measurements have been very valuable for the evaluation of the (early part of the) Twentieth Century Reanalysis Project (Compo et al., 2011; Brönnimann and Compo, 2012).

The reasons for continuing the Arosa measurements have changed many times over past decades, and it was never imagined that such a long record could be established. Figure 9 provides a historical overview of international ozone research in connection with the different phases of the LKO, which also indicates various funding periods. The justification for the LKO measurements for society can be summarised as follows:

1. to study environmental factors potentially important for the medical recovery from pulmonary TB (relevant from the beginning until around World War II),

2. to investigate air quality as an important natural resource in resort areas (as discussed in the second half of World War II),

3. to improve our understanding of atmospheric physics for improved weather forecasts (important in the 1960s and early 1970s),

4. to quantify anthropogenic ozone destruction by ODSs (mid-1970s to mid-1990s),

5. to document the effectiveness of the Montreal Protocol in saving ozone (since around the middle of the 1990s),

6. to understand the mutual relationship between climate change and global ozone depletion, and the effectiveness of the Montreal protocol (this century).

A key element for the success of LKO measurements and its continuation was the motivation of the scientists involved, i.e. Götz's early initiative and Dütsch's persistence.

From our experience, the following issues were most relevant for the successful operation of LKO over the last decades:
- Redundancy allows for increased credibility of measurements, which is particularly important for reliable long-term trend analysis. At Arosa, three Dobson and three Brewer spectrophotometers were simultaneously operated since 1998, which helps to obtain important scientific results regarding Dobson and Brewer spectrophotometers relevant within the broader context of atmospheric ozone measurements.

- Regular comparison of station instruments with standard spectrophotometers operated under the WMO umbrella are important for high-quality measurements and consistency of ozone measurements within a particular network.

- Scientific analysis and use of stratospheric ozone measurements in scientific publications and model intercomparisons not only enhance visibility of the measurements within the community, but also is a quality assessment, which might motivate scientists and technicians operating the measurements.

- Reliable techniques are important for high-quality stratospheric ozone measurements, including automation to reduce manpower costs and to make measurements less dependent on the skills of an individual operator.

It is difficult to obtain funding for continuous observations through normal science funding agencies such as the Swiss National Science Foundation (SNSF), since additional years of measurements usually do not result in novel scientific conclusions. This is the experience within other networks as well, for example NDACC. The success of the Montreal Protocol measures probably contributed to the decrease in the number of ozone measurements submitted to the World Ozone and Ultraviolet Data Center (WOUDC, presently operated by Environment and Climate Change Canada) over the past few years (Geir Braathen, personal communication, 2017). This might be exacerbated in the future as monitoring costs come under further pressure in many countries. However, we believe that such routine measurements are the responsibility of developed countries. Institutions like national meteorological services, although they also may experience financial shortfalls, are ideally suited to carry out these types of measurements since they are (in contrast to universities) capable of making long-term commitments and have the capacity to hire permanent staff. On the other hand, universities have the advantage of being able to focus on particular issues (e.g. through $\mathrm{PhD}$ theses) for a limited time, resulting in articles in peer-reviewed journals. It is important to stress the relevance of scientific activities using long-term observations. Excellent collaboration has existed between MeteoSwiss and the IAC (ETHZ) for the past three decades. However, this particular type of cooperation will be less feasible in future, as the required permanent scientific positions will typically 
no longer be available at universities. In other countries the research aspects are often integrated in the same institution (e.g. the German Weather Service (DWD) in Germany or the "Centre National de la Recherche Scientifique (CNRS)" in France). This problem still awaits a proper solution for the Swiss long-term ozone measurements.

From the very beginning, the ozone measurements from Arosa (initiated by the fruitful collaboration between Götz and Dobson) have been an important contribution both to the global network of ozone measurements and to ozone research. During the early part of the record, the International Ozone Commission (IO3C) of IAMAS coordinated the ozone measurements. Since the 1970s WMO has taken the lead, first in the framework of the Global Ozone Observing System (GOO3S), later the Global Atmosphere Watch (GAW) programme (SAG-ozone) became responsible for overseeing and coordinating stratospheric ozone measurements to obtain and maintain high-quality data suitable for long-term trend analysis. GAW might continue these activities in collaboration with other networks, such as NDACC, the present Brewer COST network, and the IO3C in order to (i) maintain and extend high-quality records of ground-based ozone stations and (ii) to continue comparisons of Dobson and Brewer measurements with different or new instruments such as SAOZ and PANDORA. GAW might represent the ground-based community as partners to the satellite community, for example within the Copernicus project and GAW also can contribute to research programs and initiatives, illustrated by the long history of ozone research connected with the LKO started by the pioneers Götz and Dütsch and continued more recently by MeteoSwiss and ETHZ under the auspices of WMO, IGACO-O3/UV, ACSO, and SPARC.

Beyond any doubt the Montreal Protocol (including enforcements) has been very successful for the protection of the ozone layer over densely populated areas, avoiding large damage by manmade chemicals as shown by extended numerical simulations (Newmann et al., 2009). In the future, when the stratosphere is expected to gradually recover from the decreasing burden of ODSs, continued observations will not only be required to document the expected increase in stratospheric ozone, but also to document the effects of climate change on stratospheric ozone, as predicted to happen by CCMs, i.e. through enhancement of the Brewer-Dobson circulation and possible other effects connected with climate change (Ball et al., 2018).

Data availability. Swiss ozone measurements can be found at WOUDC https://www.woudc.org/ (WOUDC, 2018) or from MeteoSwiss on request (Rene Stübi (rene.stuebi@meteoswiss.ch).

Competing interests. The authors declare that they have no conflict of interest.
Special issue statement. This article is part of the special issue "Quadrennial Ozone Symposium 2016 - Status and trends of atmospheric ozone (ACP/AMT inter-journal SI)". It is a result of the Quadrennial Ozone Symposium 2016, Edinburgh, United Kingdom, 4-9 September 2016.

Acknowledgements. Several present and former colleagues from MeteoSwiss contributed to the study of the history of the LKO namely, Bruno Hoegger, Kurt Aeschbacher, and Herbert Schill. We acknowledge the help of Renzo Semadeni (Kulturarchiv Arosa-Schanfigg), Peter Bollier (retired teacher in history in the Alpine Mittelschule Davos and expert in the history of Fridericianum), Hans Ulrich Pfister (Staatsarchiv des Kantons Zürich), Susanne Wernli (Gemeindeverwaltung Davos), Simon Rageth and Florian Ambauen (Rhätische Bahn AG), Klaus Pleyer (German Sanatorium, Deutsche Heilstätte, today Hochgebirgsklinik Davos), Roesli Aeschbacher (wife of Kurt Aeschbacher), and several colleagues from the Swiss Federal Archives. Finally, we would like to thank Johannes Gartmann (medical director of Sanatorium Altein (1958-1978) for valuable discussion, Wolfgang Steinbrecht (Observatorium Hohenpeissenberg of the German Weather Service (DWD) for helping to find literature related to ozone measurements and synoptic meteorology, and Bob Evans (formerly at NOAA, Boulder, USA), who supplied us with some information about the Dobson instruments operated at Arosa. We also want to thank to Rachel Vondach for drawing Fig. 2.

Edited by: Stefan Reis

Reviewed by: two anonymous referees

\section{References}

Absorption Cross-Sections of Ozone (ACSO): Status Report, 2015, Lead Authors: Johannes Orphal, Johanna Tamminen and Johannes Staehelin, World Meteorological Organization, Global Atmosphere Watch, GAW Report No. 218, Geneva, Switzerland, 2015.

Appenzeller, C., Weiss, A. K., and Staehelin, J.: North Atlantic Oscillation modulates total ozone winter trends, Geophys. Res. Lett., 27, 1131-1134, 2000.

Arblaster, J. M., Gillett, N. P., Calvo, N., Forster, P. M., Polvani, L. M., Son, S.-W., Waugh, D. W., and Young, P. J.: Stratospheric ozone changes and climate, Chapter 4 in: Scientific Assessment of Ozone Depletion: 2014, Global Ozone Research and Monitoring Project Report No. 55, World Meteorological Organization, Geneva, Switzerland, 2014.

Attmannspacher, W. and Hartmannsgruber, R.: On the Vertical Ozone and Wind Profile near the Tropopause, Pure Appl. Geophys., 106-108, 1581-1585, 1973.

Attmannspacher, W. and Hartmannsgruber, R.: 6 Jahre (1967-1972) Ozonsondierungen am Meteorologischen Observatorium Hohenpeissenberg, Berichte des Deutschen Wetterdienstes 137, Offenbach am Main, Selbstverlag der Deutschen Wetterdienstes, 1975.

Ball, W. T., Alsing, J., Mortlock, D. J., Staehelin, J., Haigh, J. D., Peter, T., Tummon, F., Stübi, R., Stenke, A., Anderson, J., Bourassa, A., Davis, S. M., Degenstein, D., Frith, S., Froidevaux, L., Roth, C., Sofieva, V., Wang, R., Wild, J., Yu, P., Ziemke, J. 
R., and Rozanov, E. V.: Evidence for a continuous decline in lower stratospheric ozone offsetting ozone layer recovery, Atmos. Chem. Phys., 18, 1379-1394, https://doi.org/10.5194/acp18-1379-2018, 2018.

Benedick, R. E.: Ozone Diplomacy, New Directions in Safeguarding the Planet, Harvard University Press, Cambridge, MA, p. 13, 1991.

Bojkov, R.: International Ozone Commission: History and activities, IAMAS Publication Series No. 2, Oberpfaffenhofen, Germany, August 2012.

Breiland, J. G.: Vertical Distribution of atmospheric ozone and its relation to synoptic meteorological conditions, J. Geophys. Res., 69, 3801-3808, 1964.

Brönnimann, S. and Compo, G. P.: Ozone highs and associated flow features in the first half of the twentieth century in different data sets, Meteorol. Z., 21, 49-59, 2012.

Brönnimann, S., Luterbacher, J., Staehelin, J., and Svendby, T.: An extreme anomaly in stratospheric ozone over Europe in 1940-1942, Geophys. Res. Lett., 31, L08101, https://doi.org/10.1029/2004GL019611, 2004a.

Brönnimann, S., Luterbacher, J., Staehelin, J., Svendby, T. M., Hansen, G., and Svenoe, T.: Extreme climate of the global troposphere and stratosphere 1940-1942 related to El Nino, Nature, 431, 971-974, 2004b.

Brunner, D., Staehelin, J., Maeder, J. A., Wohltmann, I., and Bodeker, G. E.: Variability and trends in total and vertically resolved stratospheric ozone based on the CATO ozone data set, Atmos. Chem. Phys., 6, 4985-5008, https://doi.org/10.5194/acp6-4985-2006, 2006.

Butchart, N.: The Brewer-Dobson circulation, Rev. Geophys., 52, 157-184, https://doi.org/10.1002/2013RG000448, 2014.

Compo, G. P., Whitaker, J. S., Sardeshmukh, P. D., Matsui, N., Allan, R. J., Yin, X., Gleason Jr., B. E., Vose, R. S., Rutledge, G., Bessemoulin, P., Bronnimann, S., Brunet, M., Crouthamel, R. I., Grant, A. N., Groisman, P. Y., Jones, P. D., Kruk, M. C., Kruger, A. C., Marshall, G. J., Maugeri, M., Mok, H. Y., Nordli, Ø., Ross, T. F., Trigo, R. M., Wang, X. L., Woodruff, S. D., and Worley, S. J.: The Twentieth Century Reananlysis Project, Q. J. Roy. Meteorol. Soc., 137, 1-28, https://doi.org/10.1002/qj.776, 2011.

De Muer, D. and De Backer, H.: Revision of 20 years of Dobson total ozone data at Uccle (Belgium): Fictitious Dobson total ozone trends induced by sulphur dioxide trends, J. Geophys. Res., 97, 5921-5937, 1992.

Dobson, G. M. B.: Forty Years' Research on Atmospheric Ozone at Oxford: a History, Appl. Optics, 7, 387-405, 1968.

Dobson, G. M. B. and Harrison, D. N.: Measurements of the amount of ozone in the Earth's atmosphere and its relation to other geophysical condition, P. R. Soc. London A., 110, 660-693, 1926.

Dorno, C.: Über Ozonmessungen auf spektroskopischem Wege, Meteorol. Z., 44, 385-390 (including Reply of Götz), 1927.

Dütsch, H. U.: Photochemische Theorie des atmosphärischen Ozons unter Berücksichtigung von Nichtgleichgewichtszuständen und Luftbewegungen, Inaugural Dissertation, Philosophische Fakultät II der Universität Zürich, 1946.

Dütsch, H. U.: The ozone distribution in the atmosphere, Can. J. Chem., 52, 1491-1504, 1974.

Dütsch, H. U.: An update of the Arosa ozone series to the present using a statistical instrument calibration, Q. J. Roy. Meteor. Soc., 110, 1079-1096, 1984.
Eyring, J., Arblaster, M., Cionni, I., Sedlácek, J., Perlwitz, J., Young, P. J., Bekki, S., Bergmann, D., Cameron-Smith, P., Collins, W. J., Faluvegi, G., Gottschaldt, K.-D., Horowitz, L. W., Kinnison, D. E., Lamarque, J.-F., Marsh, D. R., Saint-Martin, D., Shindell, D. T., Sudo, K., Szopa, S., and Watanabe, S.: Long-term ozone changes and associated climate impacts in CMIP5 simulations, J. Geophys. Res.-Atmos., 118, 5029-5060, https://doi.org/10.1002/jgrd.50316, 2013.

Farman, J. C., Gardiner, B. G., and Shanklin, J. D.: Large losses of total ozone in Antarctic reveal seasonal $\mathrm{ClO}_{x} / \mathrm{NO}_{x}$ interactions, Nature, 315, 207-210, 1985.

Götz, F. W. P.: Das ultraviolette Ende des Spektrums von Sonne und Sternen, Sterne, 5, 189-195, 1925.

Götz, F. W. P: Der Jahresgang des Ozongehaltes der hohen Atmosphäre, Beitr. Phys. Atmosph., 13, 15-22, 1926a.

Götz, F. W. P.: Das Strahlungsklima von Arosa, Berlin, Verlag von Julius Springer, 1926b.

Götz, F. W. P.: Zum Strahlungsklima des Spitzbergensommers, Strahlungs- und Ozonmessungen in der Königsbucht 1929, Habilitationsschrift Universität Zürich, Gerlands Beitr. zur Geophysik, 31, 119-154, 1931.

Götz, F. W. P.: Klima und Wetter in Arosa, Verlag Huber and CO. AG Frauenfeld, 1954.

Götz, F. W. P. and Volz, F.: Aroser Messungen des Ozongehaltes der unteren Troposphäre und sein Jahresgang, Z. Naturforsch. A, 6, 634-639, 1951.

Götz, F. W. P., Meetham, A. R., and Dobson, G. M. B.: The vertical distribution of ozone in the atmosphere, P. R. Soc. Lond. A, 145, 416-446, 1934.

Harris, N. R. P.: University of California Irvine: Trend Analysis of Total Ozone Data: Dissertation submitted in partial satisfaction of the requirements for the degree of Doctor of philosophy in Chemistry by Neil Richard Peter Harris, dissertation committee: Professor F. S. Rowland (Chair), Professor J. C. Hemminger and Professor J. J. Valentini, 1989.

Harris, N. R. P., Kyrö, E., Staehelin, J., Brunner, D., Andersen, S.B., Godin-Beekmann, S., Dhomse, S., Hadjinicolaou, P., Hansen, G., Isaksen, I., Jrrar, A., Karpetchko, A., Kivi, R., Knudsen, B., Krizan, P., Lastovicka, J., Maeder, J., Orsolini, Y., Pyle, J. A., Rex, M., Vanicek, K., Weber, M., Wohltmann, I., Zanis, P., and Zerefos, C.: Ozone trends at northern mid- and high latitudes - a European perspective, Ann. Geophys., 26, 1207-1220, https://doi.org/10.5194/angeo-26-1207-2008, 2008.

Hartley, W. N.: On the absorption of solar rays by atmospheric ozone, J. Chem. Soc., 39, 111-128, 1881.

Hartmannsgruber, R.: Vertikales Ozonprofil und Änderungen im troposphärischen Wettergeschehen, Annalen der Meteor., 6, 237 240, 1973.

Heath, D. F.: Non-seasonal changes in total column ozone from satellite observations, 1970-1986, Nature, 332, 219-227, 1988.

Hegglin, M. I., Fahey, D. W., McFarland, M., Montzka, S. A., and Nash, E. R.: Twenty Questions and Answers About the Ozone Layer: 2014 Update, Scientific Assessment of Ozone Depletion: 2014, World Meteorological Organization, Geneva, Switzerland, 2015.

Hoegger, B., Levrat, G., Schill, H., Staehelin, J., and Ribordy, P.: Recent developments of the Light Climatic Observatory - Ozone measuring station of the Swiss Meteorological Institute (LKO) at Arosa, J. Atmos. Terr. Phys, 54, 497-505, 1992. 
Int. Rad. Com.: International Radiation Commissions 1896 to 2008: Research into Atmospheric Radiation from IMO to IAMAS, IAMAS Publication Series, No. 1, compiled by: Hans-Jürgen Bolle, Oberpfaffenhofen, Germany, May 2008.

IOTP: Report of the International Trends Panel 1988, World Meteorological Organization, Global Ozone Research and Monitoring Project, Rept. 18, Vol. 1, 1988.

Jeannet, R., Stübi, R., Levrat, G., Viatte, P., and Staehelin, J.: Ozone balloon soundings at Payerne (Switzerland): Re-evaluation of the time series 1967-2002 and trend analysis, J. Geophys Res., 112, D11302, https://doi.org/10.1029/2005JDD006862, 2007.

Labow, G. J., McPeters, R. D., Bhartia, P. K., and Kramarova, N.: A comparison of 40 years of SBUV measurements of column ozone with data from the Dobson/Brewer network, J. Geophys. Res., 118, 7370-7378, https://doi.org/10.1002/jgrd.50503., 2013.

Levy, F.: Erfahrungen mit der Eichung der Cadmiumzelle, Meteorol. Z., 49, 139-151, 1932.

Mäder, J. A., Staehelin, J., Peter, T., Brunner, D., Rieder, H. E., and Stahel, W. A.: Evidence for the effectiveness of the Montreal Protocol to protect the ozone layer, Atmos. Chem. Phys., 10, 1216112171, https://doi.org/10.5194/acp-10-12161-2010, 2010.

Molina, M. J. and Rowland, F. S.: Stratospheric sink for chlorofluoromethanes: chlorine atom catalyzed destruction of ozone, Nature, 249, 810-812, 1974.

Newman, P. A., Oman, L. D., Douglass, A. R., Fleming, E. L., Frith, S. M., Hurwitz, M. M., Kawa, S. R., Jackman, C. H., Krotkov, N. A., Nash, E. R., Nielsen, J. E., Pawson, S., Stolarski, R. S., and Velders, G. J. M.: What would have happened to the ozone layer if chlorofluorocarbons (CFCs) had not been regulated?, Atmos. Chem. Phys., 9, 2113-2128, https://doi.org/10.5194/acp-9-21132009, 2009.

Orphal, J., Staehelin, J., Tamminen, J., Braathen, G., De Backer, M.-R., Bais, A., Balis, D., Barbe, A., Bhartia, P. K., Birk, M., Burkholder, J. W., Chance, K. V., von Clarmann, T., Cox, A., Degenstein, D., Evans, R., Flaud, J.-M., Flittner, D., GodinBeekmann, S., Gorshelev, V., Gratien, A., Hare, Ed., Janssen, C., Kyrola, E., McElroy, T., McPeters, R., Pastel, M., Petersen, M., Petropavlovskikh, I., Picquet-Varrault, B., Pitts, M., Labow, G., Rotger-Languereau, M., Leblanc, T., Lerot, C., Liu, X., Moussay, P., Redondas, A., Van Roozendael, M., Sander, S. P., Schneider, M., Serdyuchenko, A., Veefkind, P., Viallon, J., Viatte, C., Wagner, G., Weber, M., Wielgosz, R. I., and Zehner, C.: Absorption Cross-Sections of Ozone in the Ultraviolet and Visible Spectral Regions - Status Report 2015, J. Mol. Spectrosc., 327, 105-121, https://doi.org/10.1016/j.jms.2016.07.007, 2016.

Parrish, D. D., Law, K. S., Staehelin, J., Derwent, R., Cooper, O. R., Tanimoto, H., Volz-Thomas, A., Gilge, S., Scheel, H.-E., Steinbacher, M., and Chan, E.: Long-term changes in lower tropospheric baseline ozone concentrations at northern mid-latitudes, Atmos. Chem. Phys., 12, 11485-11504, https://doi.org/10.5194/acp-12-11485-2012, 2012.

Parrish, D. D., Law, K.,S., Staehelin, J., Derwent, R., Cooper, O. R., Tanimoto, H., Volz-Thomas, A., Gilge, S., Scheel, H.-E., Steinbacher, M., and Chan, E.: Lower tropospheric ozone at northern mid-latitudes: Changing seasonal cycle, Geophys. Res. Lett., 40, 1631-1636, https://doi.org/10.1002/grl.50303, 2013.

Parrish, D. D., Lamarque, J.-F., Naik, V., Horowitz, L., Shindell, D. T., Staehelin, J., Derwent, R., Cooper, O. R., Tanimoto, H., Volz-Thomas, A., Gilge, S., Scheel, H.-E., Steinbacher, M., and
Fröhlich, M.: Long-term changes in lower tropospheric baseline ozone concentrations: Comparing chemistry-climate models and observations at northern mid-latitudes, J. Geophys. Res., 119, 5719-5736, https://doi.org/10.1002/2013JD021435, 2014.

Perl, G.: Das bodennahe Ozon in Arosa, seine regelmässigen und unregelmässigen Schwankungen, Arch. Met. Geophys. Bioklimat., 14, 449-458, 1965.

Peter, T.: Microphysics and heterogeneous chemistry of polar stratospheric clouds, Annu. Rev. Phys. Chem., 48, 785-822, 1997.

Portmann, R. W., Daniel, J. S., and Ravishankara, A. R.: Stratospheric ozone depletion due to nitrous oxide: influences of other gases, Philos. T. R. Soc. B, 367, 1256-1264, https://doi.org/10.1098/rstb.2011.0377, 2012.

Ravishankara, A. R., Daniel, J. S., and Portmann, R. W.: Nitrous Oxide $\left(\mathrm{N}_{2} \mathrm{O}\right)$ : The Dominant Ozone-Depleting Substance Emitted in the 21st Century, Science, 326, 123-126, 2009.

Redondas, A., Evans, R., Stuebi, R., Köhler, U., and Weber, M.: Evaluation of the use of five laboratory-determined ozone absorption cross sections in Brewer and Dobson retrieval algorithms, Atmos. Chem. Phys., 14, 1635-1648, https://doi.org/10.5194/acp-14-1635-2014, 2014.

Rieder, H. E., Staehelin, J., Maeder, J. A., Peter, T., Ribatet, M., Davison, A. C., Stübi, R., Weihs, P., and Holawe, F.: Extreme events in total ozone over Arosa - Part 1: Application of extreme value theory, Atmos. Chem. Phys., 10, 10021-10031, https://doi.org/10.5194/acp-10-10021-2010, 2010a.

Rieder, H. E., Staehelin, J., Maeder, J. A., Peter, T., Ribatet, M., Davison, A. C., Stübi, R., Weihs, P., and Holawe, F.: Extreme events in total ozone over Arosa - Part 2: Fingerprints of atmospheric dynamics and chemistry and effects on mean values and long-term changes, Atmos. Chem. Phys., 10, 10033-10045, https://doi.org/10.5194/acp-10-10033-2010, 2010 b.

Rowland, R. S.: Stratospheric Ozone depletion, Annu. Rev. Phys. Chem., 42, 731-768, 1991.

Scarnato, B., Staehelin, J., Peter, T., Gröbner J., and Stübi, R.: Temperature and Slant Path effects in Dobson and Brewer Total Ozone Measurements, J. Geophys. Res., 114, D24303, https://doi.org/10.1029/2009JD012349, 2009.

Scarnato, B., Staehelin, J., Stübi, R., and Schill, H.: Long Term Total Ozone Observations at Arosa (Switzerland) with Dobson and Brewer Instruments (1988-2007), J. Geophys. Res., 115, D13306, https://doi.org/10.1029/2009JD011908, 2010.

Schürer, C.: Der Traum der Heilung. Eine Geschichte der Höhenkur zur Behandlung der Lungentuberkulose, Hier und Jetzt - Verlag für Kultur und Geschichte, 2017.

SFI: 75 Jahre Schweizerisches Forschungsinstitut für Hochgebirgsklima und Medizin, zusammengestellt von: Dr. Felix Suter, Malans, Redaktion: Kurt Blaser und Claus Fröhlich, Davos, Layout und Druck: Linksetting, Andy Recht, Dorfstrasse 1, 7260 Davos, 1997.

Solomon, S.: Stratospheric ozone depletion: A review of concepts and history, Rev. Geophys., 37, 275-316, 1999.

Solomon, S., Garcia, R. R., Rowland, S., and Wuebbles, D. J.: On the depletion of Antarctic ozone, Nature 321, 755-758, https://doi.org/10.1038/321755a0, 1986.

Staehelin, J. and Viatte, P.: Report on history of Light Climatic Observatory of Arosa, Report of MeteoSwiss and IACETH, in preparation, 2018. 
Staehelin, J., Thudium, J., Bühler, R., Volz-Thomas, A., and Graber, W.: Surface ozone trends at Arosa (Switzerland), Atmos. Environ., 28, 75-87, 1994.

Staehelin, J., Renaud, A., Bader, J., McPeters, R., Viatte, P., Hoegger, B., Bugnion, V., Giroud, M., and Schill, H.: Total ozone series of Arosa (Switzerland), Homogenization and data comparison, J. Geophys. Res., 103, 5827-5841, 1998a.

Staehelin, J., Kegel, R., and Harris, N. R. P.: Trend analysis of the homogenized total ozone series of Arosa (Switzerland), 19261996, J. Geophys. Res., 103, 8389-8399, 1998b.

Staehelin, J., Harris, N. R. P., Appenzeller, C., and Eberhard, J.: Ozone trends: A review, Rev. Geophys., 39, 231-290, 2001.

Staehelin, J., Brönnimann, S., Peter, T., Stübi, R., Viatte, P., and Tummon, F.: The value of Swiss long-term ozone observations for international atmospheric research, in: From Weather Observations to Atmospheric and Climate Sciences in Switzerland - celebrating 100 years of the Swiss Society for Meteorology, edited by: Willemse, S. and Furger, M., vdf Hochschulverlag AG an der ETH Zürich 2016, 325-349, 2016.

Staehelin, J., Tummon, F., Revell, L., Stenke, A., and Peter, T.: Tropospheric Ozone at Northern Mid-Latitudes: Modeled and Measured Long-Term Changes, Atmosphere, 8, 163, https://doi.org/10.3390/atmos8090163, 2017.

Steinbrecht, W., Claude, H., Köhler, U., Winkler, P., and Hoinka, K. P.: Correlations between tropopause height and total ozone: Implications for long-term changes, J. Geophys. Res, 103, 1918319192, 1998.

Steinbrecht, W., Claude, H., Köhler, U., and Winkler, P.: Interannual changes of total ozone and Northern Hemisphere circulation patterns, Geophys. Res. Lett., 28, 1191-1194, https://doi.org/10.1029/1999GL011173, 2001.

Steinbrecht, W., Froidevaux, L., Fuller, R., Wang, R., Anderson, J., Roth, C., Bourassa, A., Degenstein, D., Damadeo, R., Zawodny, J., Frith, S., McPeters, R., Bhartia, P., Wild, J., Long, C., Davis, S., Rosenlof, K., Sofieva, V., Walker, K., Rahpoe, N., Rozanov, A., Weber, M., Laeng, A., von Clarmann, T., Stiller, G., Kramarova, N., Godin-Beekmann, S., Leblanc, T., Querel, R., Swart, D., Boyd, I., Hocke, K., Kämpfer, N., Maillard Barras, E., Moreira, L., Nedoluha, G., Vigouroux, C., Blumenstock, T., Schneider, M., García, O., Jones, N., Mahieu, E., Smale, D., Kotkamp, M., Robinson, J., Petropavlovskikh, I., Harris, N., Hassler, B., Hubert, D., and Tummon, F.: An update on ozone profile trends for the period 2000 to 2016, Atmos. Chem. Phys., 17, 1067510690, https://doi.org/10.5194/acp-17-10675-2017, 2017.
Stolarski, R. S. and Cicerone, R. J.: Stratospheric chlorine: A possible sink for ozone, Can. J. Chem., 52, 1610-1615, 1974.

Stübi, R., Schill, H., Klausen, J., Vuilleumier, L., and Ruffieux, D. C.: Reproducibility of total ozone column monitoring by the Arosa Brewer spectrophotometer triad, J. Geophys. Res., 122, https://doi.org/10.1002/2016JD025735, 2017a.

Stübi, R., Schill, H., Klausen, J., Vuilleumier, L., Gröbner, J., Egli, L., and Ruffieux, D.: On the compatibility of Brewer total column ozone measurements in two adjacent valleys (Arosa and Davos) in the Swiss Alps, Atmos. Meas. Tech., 10, 4479-4490, https://doi.org/10.5194/amt-10-4479-2017, 2017b.

Trenkel, H.: Prof. Dr. Paul Götz, Falkenstein Zeitschrift der Studentenverbindungen Schwizerhusli Basel, Zähringia Bern, Carolingia Zürich, Valdesia Lausanne, 199-201, 1954.

Virchow, C.: 80 Jahre der "Der Zauberberg", über die Reaktion der Ärzte auf den Roman Thomas Mann, Pneumologie, 58, 791-802, 2004.

Walshaw, C. D.: G. M. B. Dobson - The man and his work, Planet. Space Sci., 37, 1485-1507, 1989.

Weiss, A. K., Staehelin, J., Appenzeller, C., and Harris, N. R. P.: Chemical and dynamical contributions to ozone profile trends of the Payerne (Switzerland) balloon soundings, J. Geophys. Res., 106, 22685-22694, 2001.

World Ozone and Ultraviolet Data Center (WOUDC): Ozone measurements: https://doi.org/10.14287/10000001, UV radiation measurements: https://doi.org/10.14287/10000002, last access: 3 May 2018.

Zanis, P., Maillard, E., Staehelin, J., Zerefos, C., Kosmidis, E., Tourpali, K., and Wohltmann, I.: On the turnaround of stratospheric ozone trends deduced from the re-evaluated Umkehr record of Arosa, Switzerland, J. Geophys. Res., 111, D22307, https://doi.org/10.1029/2005JD006886, 2006. 